\title{
PERAN PEMBIAYAAN BAGI HASIL MUDHARABAH DALAM PENGEMBANGAN USAHA NASABAH (Studi pada KANINDO Syariah Jatim)
}

\author{
Misbahul Munir \\ Mei Dwi Wardani
}

Fakultas Ekonomi Universitas Islam Negeri Maulana Malik Ibrahim Malang Jalan Gajayana 50 Malang

Abstract

Islamic financial services unit is designed for the creation of togetherness in bearing the risks and share the results of operations between the owner of the funds that keep their money in banks, with banks and fund managers as well as communities in need of funds to the status of the borrower or fund manager. In this study using qualitative analysis methods, qualitative analysis is a data analysis technique used in describing how the objects of research as well as outlines in the form of sentences or statements based on data collected with the aim to obtain a conclusion from the formulation of the problem. The results of this research show that mudharabah role for business customers looking from business activities managed by the customer. From an initial shortage of capital to the business generate more profits. In addition, mudharabah also have a role to the Indonesian economy. Among them are mudharabah not solely motivated by economic but also social motive that is earmarked for small communities. With mudharabah motives will alienate the public from loan sharks, but it required a very easy terms, and also mudharabah will save the Muslims from the practice of usury which is clearly unlawful.

Keywords: pembiayaan, mudlarabah, bagi hasil, shahib al-mal, mudlarib

Keberadaan bank konvensional yang ada mengutamakan sistem bunga dalam operasionalnya, sedangkan bank syariah tidak mengenal istilah bunga tetapi yang digunakan adalah istilah bagi hasil. Perbankan dengan sistem bagi hasil dirancang 
demi terbinanya kebersamaan dalam menanggung resiko dan berbagi hasil usaha antara pemilik dana yang menyimpan uangnya di bank, dengan bank selaku pengelola dana dan juga masyarakat yang membutuhkan dana yang bisa berstatus sebagai peminjam atau pengelola dana. Dengan pembiayaan yang diiringi dengan bimbingan pengelolaan modal dan usaha dapat membantu meningkatkan produktifitas usaha, yang pada akhirnya akan berpengaruh terhadap peningkatan pendapatan pedagang kecil.

Baitul Maal wat Tamwil (BMT) atau Lembaga Keuangan Syariah adalah suatu lembaga ekonomi rakyat kecil yang berupaya mengembangkan usaha-usaha produktif dan investasi dalam rangka meningkatkan kegiatan ekonomi pengusaha kecil berdasarkan prinsip syariah dan prinsip koperasi. Baitul Maal wat Tamwil (BMT) merupakan sebuah sarana pengelolaan dana dari ummat, oleh ummat dan untuk ummat (maslahah amanah) yang bebas dari riba. BMT mempunyai peluang yang sangat besar dalam menggerakkan sektor UMKM melalui optimalisasi pembiayaan bagi hasil. Pembiayaan bagi hasil (mudharabah) merupakan produk inti BMT yang membedakannya dengan sistem bunga bank konvensional.

Dalam prinsip bagi hasil terdapat tiga istilah penting, yaitu musyarakah (perjanjian kerja sama antara dua pihak atau lebih pemilik modal, baik uang maupun barang untuk membiayai suatu usaha), mudharabah (perjanjian antara pemilik modal baik uang maupun barang dengan pengusaha), muzara'ah (memberikan lahan pertanian kepada si penggarap untuk ditanami dan dipelihara dengan imbalan tertentu (presentase) dari hasil panen.

Pembiayaan akad berbasis bagi hasil seperti mudharabah dan musyarakah di Indonesia saat ini belum memiliki porsi besar sebagaimana pembiayaan dengan akad murabahah. Padahal akad dengan sistem bagi hasil lebih menerapkan prinsip keadilan, sesuai dengan konsep bank syariah. Dari berbagai data perbankan syariah, murabahah masih mendominasi produk perbankan syariah di Indonesia. Dibanding mudharabah, akad murabahah mendominasi hingga 60 persen. Murabahah merupakan perjanjian transaksi dengan cara jual beli. Sedangkan, akad mudharabah merupakan perjanjian dengan prinsip bagi hasil.

Jika digambarkan dalam sebuah grafik, maka akan didapatkan grafik mengenai prosentase nasabah terhadap produk pembiayaan pada Kanindo Syariah selama bulan Januari hingga Juni 2011. 


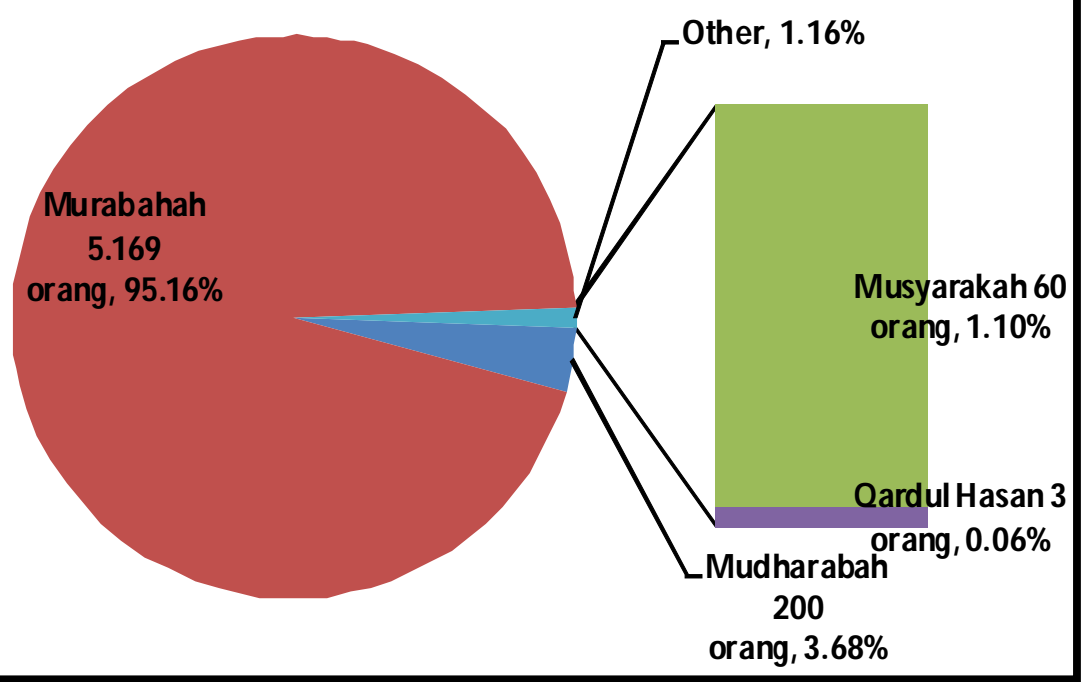

Gambar 1. Grafik Pembiayaan Nasabah

Sumber: Data diolah (2012).

Terlihat jelas dari grafik tersebut, nasabah yang berminat menggunakan produk pembiayaan mudharabah jauh lebih sedikit dari pembiayaan murabahah. Yaitu untuk produk pembiayaan mudharabah sebesar 3,68\%, pembiayaan murabahah sebesar $95,16 \%$, pembiayaan musyarakah sebesar $1,10 \%$, dan pembiayaan qardul hasan sebesar $0,06 \%$.

Selain itu, dana pembiayaan yang dikeluarkan KANINDO pada tahun sebelumnya juga menggambarkan bahwa pembiayaan mudharabah masih sedikit peminatnya.

Tabel 1. Data Pembiayaan Tahun 2009-2010

\begin{tabular}{|c|c|c|c|c|}
\hline \multicolumn{2}{|c|}{ Dana Pembiayaan } & & 2009 & 2010 \\
\hline \multirow{4}{*}{ Murabahah } & Dana & $\mathrm{Rp}$ & $0.219 .216 .840,00$ & Rp 13.698.945.377,00 \\
\hline & Pembagian & & $92,26 \%$ & $92,85 \%$ \\
\hline & Nasabah & & 12.525 orang & 13.797 orang \\
\hline & Dana & $\mathrm{Rp}$ & $811.207 .000,00$ & $820.443 .000,00$ \\
\hline \multirow[t]{3}{*}{ Mudharabah } & Pembagian & & $7,32 \%$ & $5,56 \%$ \\
\hline & Nasabah & & 994 orang & 826 orang \\
\hline & $\begin{array}{l}\text { Dana } \\
\text { Pembagian }\end{array}$ & $\mathrm{Rp}$ & $\begin{array}{l}44.415 .150,00 \\
0,40 \%\end{array}$ & $\begin{array}{c}218.301 .100,00 \\
1,48 \%\end{array}$ \\
\hline Musyarakah & $\begin{array}{l}\text { Nasabah } \\
\text { Dana }\end{array}$ & $\mathrm{Rp}$ & $\begin{array}{l}54 \text { orang } \\
1.291 .600,00\end{array}$ & $\begin{array}{l}220 \text { orang } \\
16.165 .200,00\end{array}$ \\
\hline \multirow[t]{2}{*}{ Qardul Hasan } & Pembagian & & $0,01 \%$ & $0,11 \%$ \\
\hline & Nasabah & & 2 orang & 16 orang \\
\hline \multicolumn{2}{|c|}{ Total Dana } & $\mathrm{Rp}$ & $11.076 .130 .590,00$ & Rp 14.753.854.677,00 \\
\hline \multicolumn{2}{|c|}{ Total Nasabah } & & 13.575 orang & 14.859 orang \\
\hline
\end{tabular}

Sumber: Laporan Keuangan KANINDO 
Tabel pembiayaan tersebut menunjukkan bahwa dari tahun 2009 sampai 2010 jumlah nasabah untuk pembiayaan secara keseluruhan meningkat. Namun, apabila dilihat masing-masing dari dana pembiayaan tersebut, maka pada pembiayaan mudharabah mengalami penurunan nasabah meskipun dana yang dikeluarkan meningkat.

Menurut pihak KANINDO, alasan masing-masing nasabah menggunakan produk pembiayaan tersebut bermacam-macam. Nasabah lebih sering menggunakan produk pembiayaan murabahah diantaranya karena cara pembayaran yang tidak terlalu membebani dibandingkan pembiayaan mudharabah. Di mana pada pembiayaan murabahah, nasabah dapat mengangsur pinjaman beserta bagi hasilnya setiap bulan. Sedangkan pada mudharabah, nasabah hanya membayarkan bagi hasilnya dahulu setiap bulan dan membayar pokoknya diakhir bulan perjanjian.

Selain itu, alasan lain nasabah lebih sering menggunakan pembiayaan murabahah dibandingkan mudharabah adalah besarnya bagi hasil yang ditetapkan untuk pembiayaan mudharabah, dan tergantung dengan wilayah kerja. Jika di daerah perkotaan mudharabah kurang diminati karena jangka waktu yang relatif singkat. Berbeda dengan daerah desa yang kebanyakan nasabahnya adalah petani, di mana jangka waktu pembiayaan mudharabah sesuai dengan masa panen petani.

Menurut uraian data dan grafik di atas mengenai pembiayaan mudharabah yang meningkat pada sisi dana namun pada sisi nasabah turun, padahal dana pembiayaan mudharabah lebih dikhususkan untuk pengembangan usaha masyarakat kecil. Berdasarkan uraian inilah penulis ingin lebih mengetahui kontribusi pembiayaan dana mudaharabah terhadap usaha masyarakat dengan judul "Peran Pembiayaan Bagi Hasil Mudharabah Dalam Pengembangan Usaha Nasabah (Studi Pada Kanindo Syariah Jatim)".

Atas dasar latar belakang tersebut di atas, maka penelitian ini bertujuan untuk mengetahui sistem dan prosedur mengenai pembiayaan bagi hasil mudharabah di Kanindo Syariah, mengetahui perhitungan bagi hasil mudharabah di Kanindo Syariah, serta mengetahui kontribusi pembiayaan mudharabah terhadap perkembangan usaha nasabah di Kanindo Syariah.

Menurut Karim (2003:180), mudharabah adalah akad yang telah dikenal oleh umat muslim sejak zaman nabi, bahkan telah dipraktikkan oleh bangsa arab sebelum turunnya Islam. Ketika Nabi Muhammad SAW berprofesi sebagai pedagang, beliau melakukan akad mudharabah dengan Khadijah. Dengan demikian, ditinjau dari segi hukum Islam, maka praktik mudharabah ini dibolehkan, baik dalamAl-Qur'an, Sunnah, maupun Ijma'.

Dalam praktik mudharabah antara Khadijah dan Nabi, saat itu Khadijah mempercayakan barang dagangannya untuk dijual oleh Nabi Muhammad SAW ke luar negeri. Dalam kasus ini, Khadijah berperan sebagai pemilik modal (shahib almaal) sedangkan Nabi Muhammad SAW berperan sebagai pelaksana usaha (mudharib). Bentuk kontrak antara dua pihak dimana satu pihak berperan sebagai 
pemilik modal dan mempercayakan sejumlah modalnya untuk dikelola oleh pihak kedua, yakni si pelaksana usaha, dengan tujuan untuk mendapatkan untung disebut akad mudharabah. Atau singkatnya, akad mudharabah adalah persetujuan kongsi antara harta dari salah satu pihak dengan kerja dari pihak lain. Mudharabah juga disebut qiradh atau muqaradah. Makna keduanya sama. Mudharabah adalah istilah yang digunakan di Irak, sedangkan istilah qiradh digunakan oleh masyarakat Hijaz.

Disebut juga qiradh yang berasal dari kata Al Qardhu yang berarti Al Qath'u (potongan), karena pemilik memotong sebagian hartanya untuk diperdagangkan dan memperoleh sebagian keuntungannya. Menurut Antonio (1999:149), Mudharabah berasal dari kata dharb yang artinya memukul atau berjalan. Pengertian memukul atau berjalan ini lebih tepatnya adalah proses seseorang memukulkan kakinya dalam menjalankan usaha. Secara teknis, Mudharabah adalah akad kerjasama usaha antara dua pihak di mana pihak pertama (shahibul maal) menyediakan seluruh (100\%) modal, sedangkan pihak lainnya menjadi pengelola. Karim (2003: 91) menjelaskan bahwa Mudharabah adalah bentuk kerjasama antara dua atau lebih pihak dimana pemilik modal (shahib al-maal) mempercayakan sejumlah modal pada pengelola (mudharib) dengan suatu perjanjian pembagian keuntungan. Dengan kata lain, kerjasama ini merupakan paduan antara modal kas seutuhnya dari shahib al-maal dan modal keahlian sepenuhnya oleh mudharib.

Keuntungan secara mudharabah dibagi menurut kesepakatan yang dituangkan dalam kontrak, sedangkan apabila rugi ditanggung oleh pemilik modal selama bukan akibat kelalaian dari pengelola, tetapi seandainya kerugian diakibatkan karena kecurangan atau kelalaian si pengelola, maka si pengelola harus bertanggung jawab atas kerugian tersebut.

Menurut Qardhawi (1985:313), syari'at Islam mensyaratkan di dalam muamalah seperti ini, oleh para fuqaha diistilahkan dengan mudharabah atau qiradh, bahwa antara kedua belah pihak harus sama-sama mendapatkan keuntungan bila beruntung dan sama-sama menanggung kerugian jika rugi, dan berapa bagian (persen) keuntungan dan kerugian yang harus ditanggung haruslah sesuai dengan kesepakatan mereka. Dengan demikian kerjasama antara modal dan pekerjaan merupakan kerjasama merupakan kerjasama antara dua orang yang berserikat, masing-masing akan mendapatkan bagiannya, sedikit ataupun banyak.

Secara umum Mudharabah terbagi dalam dua jenis, yaitu mudharabah muthlaqah dan mudharabah muqayyadah. mudharabah muthlaqah adalah bentuk kerjasama antara shahibul maal dan mudharib yang cakupannya sangat luas dan tidak dibatasi oleh spesifikasi jenis usaha, waktu, dan daerah bisnis. Sedangkan mudharabah muqayyadah adalah kebalikan dari mudharabah muthlaqah. Si mudharib dibatasi dengan batasan jenis usaha, waktu, atau tempat usaha. Adanya pembatasan ini seringkali mencerminkan kecenderungan umum si shahibul maal dalam memasuki dunia usaha. 
Dalam praktik perbankan syariah modern, kini dikenal dua bentuk mudharabah muqayyadah, yakni yang on balance-sheet dan yang off balance-sheet. Dalam mudharabah muqayyadah on balance sheet, aliran dana terjadi dari satu nasabah investor ke sekelompok pelaksana usaha dalam beberapa sektor terbatas, misalnya pertanian, manufaktur dan jasa. Nasabah investor lainnya mungkin mensyaratkan dananya hanya boleh dipakai untuk pembiayaan di sektor pertambangan, property, dan pertanian. Selain berdasarkan sektor, nasabah investor dapat saja mensyaratkan berdasarkan jenis akad yang digunakan, misalnya hanya boleh digunakan berdasarkan akad penjualan cicilan saja, atau penyewaan cicilan saja, atau kerja sama usaha saja. Skema ini disebut on balance sheet karena dicatat dalam neraca bank (Karim, 2003:189).

Dalam mudharabah muqayyadah off balance sheet, aliran dan berasal dari satu nasabah investor kepada satu nasabah pembiayaan (yang dalam bank konvensional disebut debitur). Di sini, bank syariah bertindak sebagai arranger saja. Pencatatan transaksinya di bank syariah dilakukan secara off balance sheet. Sedangkan bagi hasilnya hanya melibatkan nasabah investor dan pelaksana usaha saja. Besar bagi hasil tergantung kesepakatan antara nasabah investor dan nasabah pembiayaan. Bank hanya memperoleh arranger fee. Skema ini disebut off balance sheet karena transaksi ini tidak dicatat dalam neraca bank, tetapi hanya dicatat dalam rekening administratif saja.

\section{METODE}

Jenis penelitian yang digunakan adalah kualitatif dengan pendekatan deskriptif. Metodelogi kualitatif adalah penelitian yang dilakukan pada kondisi obyek yang alami, peneliti sebagai instrumen kunci, teknik pengumpulan data dilakukan secara gabungan, data yang dihasilkan bersifat deskriptif dan analisis data dilakukan secara induktif dan penelitian ini lebih menekankan makna dari pada generalisasi.

Penelitian deskriptif adalah penelitian yang memandu peneliti untuk mengekplorasi dan atau memotret situasi yang akan diteliti secara menyeluruh, luas dan mendalam. Adapun penelitian deskriptif menurut Arikunto (2002:309) adalah penelitian yang dimaksudkan untuk mengumpulkan informasi mengenai status suatu gejala yang ada, yaitu keadaan gejala menuntut apa adanya pada saat peneliti dilakukan. Tujuan dari penelitian deskriptif ini adalah membuat deskripsi, gambaran secara sistematis, aktual dan akurat mengenai fakta-fakta, sifat serta hubungan antar fenomena yang dimiliki.

Berdasarkan uraian tersebut dapat dikemukakan bahwa penelitian deskriptif ini berusaha menggambarkan objek penelitian berdasarkan fakta dan data serta kejadian berusaha menghubungkan kejadian-kejadian atau objek penelitian sekaligus menganalisanya berdasarkan konsep-konsep yang telah dikembangkan sebelumnya sehingga memudahkan peneliti dalam memecahkan masalah. 
Sedangkan lokasi penelitian dilaksanakan di KANINDO Syariah Jatim yang berpusat di Dau-Malang. KANINDO adalah singkatan dari Koperasi Agro Niaga Indonesia. KANINDO merupakan lembaga keuangan berbasis syariah yang salah satu produknya adalah produk bagi hasil mudharabah. Dari KANINDO Syariah ini penulis akan lebih mudah memperoleh informasi mengenai nasabah yang menggunakan sistem pembiayaan mudharabah.

Adapun jenis data yang akan disajikan merupakan data primer dan data sekunder. Menurut Indrianto, et al. (1999:146), data primer adalah sumber data penelitian yang diperoleh secara langsung dari sumber asli tanpa melalui perantara. Data ini mempunyai dua metode atau teknik dalam pengumpulan datanya, yaitu metode interview (wawancara) dan observasi atau pengamatan langsung pada objek selama kegiatan penelitian lapangan. Adapun yang menjadi narasumber atau informan dalam penelitian ini adalah Kepala Cabang KANINDO Syariah yang mengetahui secara keseluruhan kegiatan yang ada di KANINDO Syariah. Serta anggota yang menggunakan produk pembiayaan mudharabah.

\section{HASIL DAN PEMBAHASAN}

\section{Sistem dan Prosedur Pembiayaan Bagi Hasil Mudharabah}

Mudharabah adalah akad kerjasama usaha antara dua pihak di mana Kanindo (shahib al-mal) menyediakan seluruh (100\%) modal sedangkan pihak lainnya (nasabah atau mudharib) menjadi pengelola. Keuntungan usaha dibagi menurut nisbah yang disepakati dalam kontrak, sedangkan apabila rugi ditanggung pemilik modal selama kerugian itu bukan akibat kelalaian pengelola. Akan tetapi apabila kerugian itu disebabkan karena kecurangan atau kelalaian pengelola maka pengelola harus bertanggung jawab atas kerugian tersebut. Berdasarkan hasil wawancara dengan Kepala Cabang Dau, diperoleh skema pembiayaan mudharabah pada Kanindo Syariah adalah sebagai berikut.

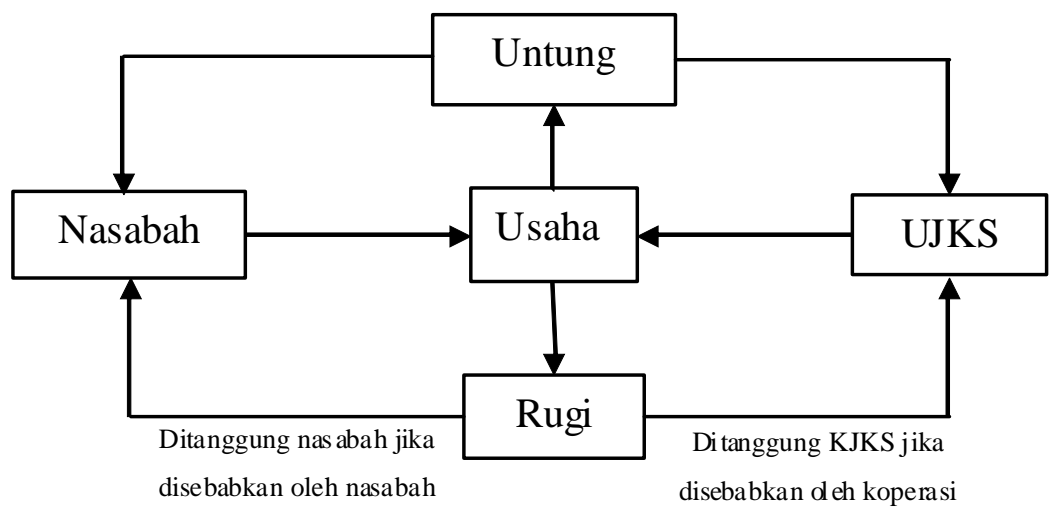

\section{Gambar 2. Skema Pembiayaan Mudharabah}

Sumber: Wawancara dengan Pak Farhan. Selasa, 20 September 2011 jam 09.00 
Nasabah yang menggunakan produk pembiayaan mudharabah pada tahun 2009 hingga tahun 2011 bulan Juni ini sebanyak kurang lebih 2.020 orang nasabah. Dengan perincian sebagai berikut:

Tabel 2. Data nasabah

\begin{tabular}{lll}
\hline Waktu & Jumlah Nasabah & Jumlah Dana Pembiayaan \\
\hline 2009 & 994 orang & Rp. 811.207.000 \\
2010 & 826 orang & Rp. 820.443.000 \\
Januari-Juni 2011 & 200 orang & Belum Diketahui \\
\hline Total & 2.020 orang & \\
\hline
\end{tabular}

Sumber: Data Nasabah tahun 2009-2011

Adapun alur atau skema pembiayaan mudharabah pada KANINDO Syariah sama seperti lembaga keuangan syariah yang lain, yaitu sebagai berikut:

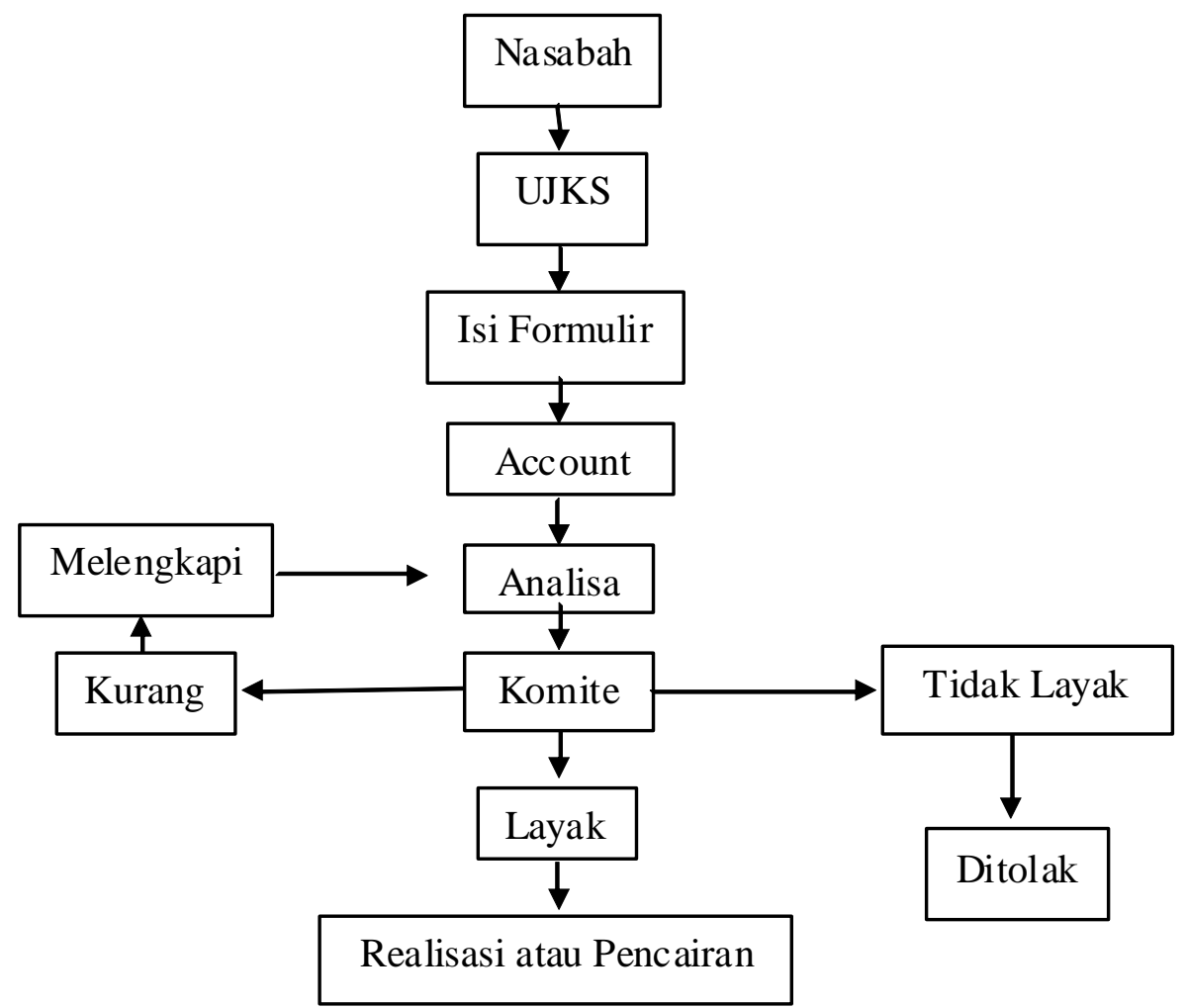

Sumber: Pengajuan Pinjaman, Kanindo

Pada pembiayaan mudharabah, pihak Kanindo memiliki beberapa syarat yang lain sebelum membuat akad dengan nasabah. Seperti nasabah haruslah yang pernah 
menggunakan pembiayaan pada Kanindo lebih dari dua kali. Hal ini dimaksudkan agar pihak Kanindo memiliki data yang sebenarnya tentang nasabah. Karena pembiayaan mudharabah adalah akad pembiayaan yang pembayaran pokoknya dilakukan di akhir pembiayaan, sehingga memiliki banyak resiko jika nasabah bukanlah orang yang pernah meminjam sebelumnya. Bisa juga nasabah bukanlah orang yang pernah meminjam sebelumnya, tetapi pihak Kanindo sudah memastikan bahwa pihaknya mengenal dengan baik calon nasabah tersebut. Dengan demikian, maka pihak Kanindo memiliki data-data mengenai calon nasabah tersebut.

Usaha yang dibiayai pada pembiayaan mudharabah oleh Kanindo adalah usaha yang produktif, dan yang lebih banyak menggunakan pembiayaan mudharabah adalah usaha di bidang pertanian. Dengan perhitungan misalkan pendapatan per panen, keuntungan 1 hektar yang telah dikurangi biaya-biaya yang ada. Ketika lembaga keuangan memberikan pinjaman uang kepada nasabah, lembaga tersebut tentu saja mengharapkan uangnya kembali. Karenanya, untuk memperkecil risiko (uangnya tidak kembali, sebagai contoh), dalam memberikan kredit lembaga keuangan harus mempertimbangkan beberapa hal yang terkait dengan itikad baik (willingness to pay) dan kemampuan membayar (ability to pay) nasabah untuk melunasi kembali pinjaman beserta bunganya, dasarnya adalah 5C. Hal-hal tersebut terdiri dari character (kepribadian), capacity (kapasitas), capital (modal), colateral (jaminan), dan condition of economy (keadaan perekonomian), atau sering disebut sebagai 5C (panca $\mathrm{C}$ ).

Setelah akad pembiayaan mudharabah disetujui, nasabah akan ditanya lebih lanjut terkait berapa dana yang dibutuhkan, usaha apa yang akan dijalankan, serta bagaimana kondisi keuangan nasabah. Nasabah akan diberikan form terkait dana pembiayaan mudharabah. Ada sekitar lima form yang diberikan. Di antaranya form berita acara pemeriksaan barang, form akad pembiayaan mudharabah, form surat permohonan pembiayaan, form data kekayaan, dan yang terakhir adalah form analisa laba-rugi nasabah.

Jika nasabah sudah menyerahkan form dan berkas-berkas yang diminta oleh Kanindo Syariah, maka pihak Kanindo Syariah akan memulai proses dengan menyurvei nasabah secara langsung. Dalam proses ini, dibutuhkan waktu sekitar dua minggu karena jumlah nasabah yang ingin menggunakan pembiayaan pada Kanindo cukup banyak, sedangkan proses survei juga membutuhkan waktu yang lama. Jika pihak Kanindo telah selesai melakukan survei, maka akan diputuskan apakah nasabah tersebut bisa mendapatkan pembiayaan atau tidak sesuai dengan kesamaan form yang diisi dengan hasil survei serta perhitungan yang dilakukan oleh pihak Kanindo sendiri.

Dalam pembiayaan mudharabah, ada beberapa hal yang masih dipertimbangkan oleh Kanindo dalam penyaluran dana. Di antaranya adalah nasabah yang menggunakan dana mudharabah adalah nasabah yang telah meminjam dana pada Kanindo lebih dari dua kali, dalam hal ini diharapkan agar nasabah tersebut mampu 
untuk diberi kepercayaan oleh Kanindo. Kemudian usaha yang dikelola benarbenar usaha produktif sehingga usaha tersebut mampu memberikan keuntungan maksimal bagi nasabah dan juga Kanindo. Jika pembiayaan mudharabah tidak benar-benar disurvei, maka yang timbul adalah aliran dana yang akan macet karena pokok pembiayaan yang jumlahnya besar dikhawatirkan tidak terbayar. Hal inilah yang selalu diperhitungkan oleh Kanindo karena dana yang dimiliki Kanindo merupakan dana dari pihak ketiga, sehingga dalam perputarannya dibutuhkan kejujuran dalam setiap pembiayaannya.

Dalam pembiayaan mudharabah yang dilakukan oleh Kanindo, terdapat analisa yang dilakukan oleh pihak Kanindo sesuai dengan syarat-syarat yang diajukan sebelum akad pembiayaan. Adapun form-form yang harus diisi oleh nasabah adalah form analisa laba rugi nasabah, data kekayaan, surat permohonan pembiayaan, akad pembiayaan mudharabah, dan berita acara pemeriksaan.

\section{Penerapan dan Perhitungan Sistem Bagi Hasil Mudharabah}

Mudharabah adalah salah satu produk pembiayaan yang sasarannya adalah masyarakat yang memiliki usaha produktif. Mudharabah adalah pembiayaan usaha dimana pihak pertama atau Kanindo sebagai shahibul maal (pemilik dana), dan pihak kedua adalah nasabah selaku mudharib (pengelola). Dalam hal ini, seluruh dana keluar dari Kanindo, sedangkan nasabah hanya menjalankan usaha dengan menggunakan dana yang telah dikeluarkan oleh pihak Kanindo.

Penerapan sistem bagi hasil mudharabah pada Kanindo Syariah sama halnya dengan teori tentang mudharabah dimana pembiayaan yang bagi hasilnya diperoleh dari keuntungan usaha yang dijalankan dengan porsi pembagian yang telah disepakati bersama pada awal kontrak. Dalam hal ini, pihak Kanindo Syariah telah menetapkan nilai bagi hasil yang diberikan kepada nasabah. Yaitu untuk pembiayaan mudharabah sebesar 30:70. Untuk ketetapan besarnya nisbah bagi hasil, menurut Kanindo sudah diperhitungkan sesuai dengan kemampuan nasabah dan asumsi keuntungan dari usaha nasabah.

Dari data-data yang telah diberikan oleh nasabah kepada pihak Kanindo dan telah benar-benar disurvei oleh Account Officer, pihak Kanindo bisa memperhitungkan berapa besar keuntungan yang akan diperoleh oleh nasabah dalam usahanya. Besarnya pinjaman yang diajukan oleh nasabah akan diasumsikan $10 \%$ dari pinjaman tersebut sebagai keuntungan yang akan diperoleh nasabah. Untuk selanjutnya, pihak Kanindo tinggal menghitung berapa bagi hasil yang akan diberikan nasabah kepada Kanindo. Jika diambil contoh bahwa nasabah menggunakan dana mudharabah sebesar Rp. 3.000.000,00. Maka asumsi untuk keuntungan nasabah adalah sebagai berikut:

- Dana yang digunakan : :Rp. 3.000.000,00

- Asumsi keuntungan $: 10 \%$ x Rp. $3.000 .000,00=$ Rp. $300.000,00$ 
- Nisbah Bagi Hasil : $3 \%$ untuk nasabah

- $\quad$ Perhitungan nisbah : 3\% x Rp. 300.000,00 = Rp. 90.000,00

Dari perhitungan tersebut, maka dapat diambil kesimpulan bahwa dari dana yang digunakan sebesar Rp. 3.000.000,00 akan dibayarkan nasabah kepada pihak Kanindo sebagai bagi hasil sebesar Rp. 90.000,00 setiap bulannya selama 6 bulan. Bila ditulis di dalam tabel adalah sebagai berikut.

Tabel 3. Kartu Pembiayaan Mudharabah

\begin{tabular}{|c|c|c|c|c|c|c|}
\hline \multirow[b]{2}{*}{$\mathbf{K e}$} & \multirow[b]{2}{*}{ Tgl. } & \multicolumn{3}{|c|}{ Angsuran } & \multirow{2}{*}{$\begin{array}{c}\text { Saldo } \\
\text { Pembiayaan }\end{array}$} & \multirow[b]{2}{*}{$\begin{array}{l}\text { Ket. } \\
\text { Paraf }\end{array}$} \\
\hline & & Pokok & $\begin{array}{c}\text { Bagi Hasil } \\
\text { P.M }\end{array}$ & Denda & & \\
\hline 1. & $1 / 1 / 2010$ & - & 90.000 & - & 3.000 .000 & \\
\hline 2. & $1 / 2 / 2010$ & - & 90.000 & - & 3.000 .000 & \\
\hline 3. & $1 / 3 / 2010$ & - & 90.000 & - & 3.000 .000 & \\
\hline 4. & $1 / 4 / 2010$ & - & 90.000 & - & 3.000 .000 & \\
\hline 5. & $1 / 5 / 2010$ & - & 90.000 & - & 3.000 .000 & \\
\hline 6. & $1 / 6 / 2010$ & 3.000 .000 & 90.000 & - & 0 & \\
\hline
\end{tabular}

Sumber: Kartu Pembiayaan Kanindo

\section{Analisis Pembiayaan Bagi Hasil Mudharabah}

Setelah perhitungan mengenai bagi hasil mudharabah tersebut, dapat diambil kesimpulan mengenai pola perhitungan dan pembagian mengenai bagi hasil antara nasabah dan pihak Kanindo. Pihak Kanindo telah menentukan besarnya porsi bagi hasil yang diberikan kepada nasabah. Nisbah bagi hasilnya yaitu 30:70, atau 30 untuk porsi nasabah dan 70 untuk porsi Kanindo. Jika dari perhitungan didapatkan bahwa nasabah membayarkan sebesar 3\% pada Kanindo atau Rp. 90.000,00. Maka porsi yang diperoleh nasabah adalah sebesar $7 \%$ dari estimasi keuntungan yang telah diperhitungkan sebelumnya yaitu sebesar Rp. 210.000,00. Dari hasil tersebut, maka keuntungan yang didapatkan oleh nasabah selama pembiayaan adalah sebesar Rp. 1.260.000,00. Dari hasil keuntungan tersebut, maka nasabah bisa mengembangkan usahanya.

Dengan demikian, untuk setiap bulannya nasabah mampu mengembangkan usahanya dengan menggunakan modal dari hasil keuntungan yang telah dibagi sesuai dengan porsi nisbah bagi hasilnya. Pembiayaan mudharabah yang diharapkan mampu mengembangkan usaha nasabah akhirnya akan mampu mendayaupayakan dana yang disalurkannya untuk kepentingan usaha nasabah. Terkait dengan bagi hasil yang memiliki prosentasi cukup tinggi, menurut Kanindo Syariah itu dikarenakan dana yang dimiliki oleh Kanindo merupakan dana yang bersumber dari masyarakat atau dengan kata lain dana tersebut adalah dana yang dihasilkan dari tabungan atau simpanan nasabah. Nisbah yang dikenakan cukup tinggi karena Kanindo Syariah sendiri tidak memiliki penyokong dana lain selain nasabah. Maka jika terjadi 
kecurangan dalam transaksi ataupun akad kerjasama, maka Kanindo tidak memiliki alternative lain. Tidak seperti lembaga keuangan lain yang jika terjadi masalah, maka akan dibantu dana oleh Bank Indonesia. Untuk itulah Kanindo memberikan perbedaan tentang nisbah bagi hasilnya dengan lembaga keuangan lainnya.

Ketika ada kerugian pada pihak nasabah, maka Kanindo akan melakukan pembinaan, memberikan tenggang waktu dan kesempatan. Re-schedule (akad baru) atau mengembalikan pokok. Jika masih tidak bisa, maka akan di musyawarahkan. Dengan kata lain, ketika nasabah merugi, maka pihak Kanindo memberikan dua opsi pilihan. Yang pertama adalah memberikan tenggang waktu atau dengan kata lain adalah re-schedule (akad baru). Dan yang kedua adalah nasabah diminta untuk mengembalikan pokoknya saja tanpa bagi hasil. Jika dua opsi stersebut masih belum bisa mengatasi, maka akan diadakan musyawarah antara pihak Kanindo dan nasabah terkait usaha yang dijalankan.

Ketika nasabah tidak sanggup melunasi pokok, maka jaminan yang diserahkan kepada Kanindo akan dijual oleh pihak Kanindo. Harga jaminan disesuaikan dengan harga yang berlaku. Misalkan jaminan yang diberikan nasabah adalah sepeda motor, dan uang pembiayaan yang diberikan oleh Kanindo sebesar Rp. 5.000.000,-. Setelah barang jaminan terjual, maka pihak Kanindo akan mengambil uang hasil penjualan barang jaminan tersebut sebesar dana yang dibiayakan kepada nasabah, dan sisa penjualan tersebut akan dikembalikan kepada nasabah. Dengan demikian, nasabah dimudahkan oleh Kanindo dalam hal penyelesaian pembiayaan.

\section{Kontribusi Pembiayaan Bagi Hasil Mudharabah bagi Nasabah}

Pembiayaan mudharabah saat ini memang belum sepenuhnya dipergunakan secara maksimal. Ada beberapa kendala yang memang dihadapi oleh Kanindo seperti yang telah diuraikan di atas. Peran pembiayaan mudharabah bagi usaha nasabah memang sangat besar. Namun tidak menutup kemungkinan adanya hambatan yang ditemui oleh nasabah dalam pembiayaannya. Karena usaha yang dijalankan oleh nasabah bervariasi, maka peran maupun masalah yang dihadapi juga berbeda. Berikut adalah wawancara dengan beberapa nasabah yang menggunakan produk pembiayaan mudharabah.

Toko Kelontong Ibu Sri. Pembiayaan mudharabah adalah pembiayaan yang digunakan untuk membantu masyarakat dalam rangka mengembangkan usaha yang dimiliki. Salah satu contohnya adalah ibu Sri yang seorang ibu rumah tangga dan memiliki usaha toko kelontong di rumahnya. Pada awalnya usaha yang dijalankan oleh ibu Sri adalah menjual kue kecil-kecilan. Namun seiring berjalannya waktu, usaha tersebut mulai berkembang. Tidak hanya kue-kue, Ibu Sri juga mulai menambah barang dagangannya seperti sembako dan lain-lain, dan untuk menunjang usahanya, ibu Sri menggunakan pembiayaan mudharabah pada Kanindo Syariah. 
Dengan menggunakan pembiayaan mudharabah, nasabah bisa memperbanyak barang dagangannya. Dan terbukti dari usaha yang awalnya hanya menjual makanan ringan, kini juga menjual barang-barang kebutuhan rumah tangga sehari-hari. Selain itu, jika dilihat dari jumlah pembeli, maka terlihat jumlah pembeli yang semakin banyak. Hal ini dikarenakan adanya minuman dingin yang dijual.

Dana mudharabah yang digunakan untuk membeli inventaris toko sangat menguntungkan pemilik. Mereka menyiasati usahanya dengan menjual barang dengan harga yang sesuai. Dengan demikian usaha yang dijalankan perlahan akan mengalami peningkatan baik dalam segi jumlah barang dagangan, peningkatan pembeli dan juga peningkatan pendapatan.

Dari wawancara dengan pemilik, dapat disimpulkan bahwa pemilik mengalami kendala modal dalam usahanya sehingga pemilik menggunakan pembiayaan mudharabah. Selain itu peran pembiayaan bagi hasil mudharabah sangat terlihat pada usaha nasabah. Pembiayaan yang pada awalnya untuk menambah inventaris dan barang dagangan akhirnya mampu meningkatkan pendapatan. Pemilik juga mampu mengembangkan usaha yang bermula dari usaha kecil-kecilan menjadi toko yang menyediakan kebutuhan dan perlengkapan sehari-hari. Untuk pembayaran dan pembiayaan, dilakukan dengan cara hasil dari pendapatan toko diambil sebagian untuk pembayaran bagi hasil. Sedangkan untuk pokok pembiayaan, menggunakan uang tabungan atau gaji dari suami Ibu Sri

Usaha Gypsum dan Toko Bapak Mulyono. Bapak Mulyono adalah pengusaha gypsum. Di awal usahanya, beliau hanya menjalankan usaha tersebut secara kecilkecilan. Namun, usaha tersebut perlahan mulai berkembang. Dengan semakin banyaknya pembeli (pemesan) gypsum, maka modal yang dibutuhkan untuk menjalankan usaha juga semakin besar. Hingga akhirnya Pak Mul memutuskan untuk meminjam dana pembiayaan pada Kanindo Syariah.

Untuk menghemat biaya pengiriman, maka nasabah mempergunakan dana pembiayaan tersebut untuk membeli kendaraan. Hal tersebut sangat membantu usaha gypsum nasabah. Sehingga saat ini, nasabah semakin mudah dalam menjalankan usahanya. Walaupun demikian untuk masalah pembayaran atau pendapatan yang diterima oleh nasabah masih mengalami kesulitan. Karena tidak semua konsumennya melakukan pembelian secara tunai, ada juga yang melakukan pembelian secara kredit.

Dalam hal ini, nasabah menjelaskan bagaimana kondisi pendapatan usahanya. Untuk menambah penghasilan, nasabah juga membuka loket pembayaran listrik dan telepon. Hal ini mampu memberikan penghasilan bertambah dan bisa dipergunakan untuk membayar bagi hasil kepada Kanindo. Sehingga dapat disimpulkan bahwa peran yang diberikan oleh Kanindo Syariah melalui pembiayaan bagi hasil mudharabah terlihat dari penghasilan yang bertambah serta kegiatan usaha yang juga semakin berkembang. 
Penjual Daging Ibu Rombati. Contoh lain nasabah yang menggunakan dana mudharabah untuk usaha adalah ibu Rombati. Beliau menggunakan dana pembiayaan mudharabah untuk usaha dagang daging. Setelah menggunakan dana pembiayaan mudharabah, ternyata penghasilan yang diperoleh dari usahanya masih belum sesuai seperti yang diinginkan.

Dalam sebuah usaha, memang diperlukan adanya perbedaan antara keperluan pribadi dengan keperluan usaha. Seperti yang terjadi pada usaha ibu Rombati, beliau masih belum bisa memisahkan keuangan usaha dan keuangan pribadi yang pada akhirnya akan mengakibatkan keuangan menjadi bermasalah. Dalam keadaan seperti ini, pihak Kanindo akan memberikan masukan kepada nasabah, atau juga pelatihan.

Kebutuhan Konsumtif Ibu Paini. Selain contoh tersebut, tidak semua nasabah yang menggunakan dana mudharabah digunakan untuk mengembangkan usahanya. Ada juga nasabah yang menggunakan dana pembiayaan mudharabah untuk keperluan pribadi seperti untuk berobat atau juga untuk membayar sekolah. Seperti yang dilakukan oleh Ibu Paini. Beliau menggunakan pembiayaan mudharabah untuk memperbaiki rumah dan untuk membayar iuran bulanan anaknya yang masih SD. Terbukti bahwa dana pembiayaan bagi hasil mudharabah tidak hanya bagi mereka yang memiliki usaha. Hal ini tidak sesuai dengan teori yang ada yang menjelaskan mengenai pembiayaan mudharabah.

Dari penjelasan yang diberikan oleh ibu Paini, maka disini dapat ditarik kesimpulan bahwa dana pembiayaan mudharabah tidak sepenuhnya dipergunakan untuk kegiatan usaha. Ibu Paini adalah salah satu contoh nasabah yang menggunakan mudharabah namun dipergunakan untuk kebutuhan konsumtif. Hal ini dikarenakan arisan yang diperoleh ibu Paini masih kurang beberapa bulan lagi. Sehingga apabila beliau menggunakan produk pembiayaan mudharabah, beliau tidak perlu memikirkan bulanannya karena bagi hasil per bulan tidak terlalu banyak. Dan ketika arisan itu keluar, maka uang tersebut dapat disetorkan kembali kepada pihak Kanindo. Setelah penulis konfirmasi kepada pihak Kanindo, mereka memberikan keterangan bahwa, sulit memberikan alasan untuk menolak ketika orang tersebut datang untuk meminjam dana dengan alasan pribadi tersebut.

Dari uraian tersebut, dapat disimpulkan bahwa pihak Kanindo telah menjelaskan kepada nasabah mengenai dana pembiayaan mudharabah. Namun, ketika nasabah tetap ingin menggunakan pembiayaan tersebut, maka pihak Kanindo mencari alternatif lain yaitu dengan mencari data mengenai keluarga nasabah yang memiliki usaha. Hal ini dimaksudkan agar dana tersebut bisa diatasnamakan usaha dari keluarga nasabah. Dan apabila akad telah disepakati, maka untuk selanjutnya pihak Kanindo mempunyai kebijakan untuk tidak akan lagi memberikan pinjaman dana kepada nasabah tersebut.

Dari jawaban yang diberikan oleh nasabah, maka dapat disimpulkan bahwa peran pembiayaan mudharabah bagi usaha nasabah terlihat dari kegiatan usaha 
yang dikelola oleh nasabah. Dari yang awalnya kekurangan modal hingga usahanya menghasilkan keuntungan lebih. Selain itu, dari usaha nasabah yang terkendala modal hingga usaha tersebut mampu memenuhi pesanan konsumen. Namun tidak semua usaha yang berjalan mendapatkan keuntungan seperti yang diharapkan. Ada juga usaha yang masih saja belum mengalami perkembangan. Hal ini disebabkan karena nasabah masih belum bisa mengatur keuangannya sehingga mengakibatkan dana pembiayaan tersebut tercampur dengan keuangan sehari-hari.

Dari beberapa nasabah yang telah memberikan keterangan kepada penulis, penulis juga menemukan adanya nasabah yang tidak menggunakan dana pembiayaan mudharabah untuk usaha atau dengan kata lain, dana yang dipinjam digunakan untuk kebutuhan konsumtif. Hal ini tidak sesuai dengan syarat mudharabah dimana dana yang seharusnya digunakan untuk usaha produktif namun pada kenyataannya tidak. Dan untuk selanjutnya pihak Kanindo mempunyai kebijakan untuk tidak akan lagi memberikan pinjaman dana kepada nasabah tersebut.

Selain itu, pembiayaan mudharabah juga memiliki peran bagi perekonomian Indonesia. Diantaranya adalah pembiayaan mudharabah tidak hanya semata-mata bermotifkan ekonomi tetapi juaga motif sosial yaitu diperuntukkan untuk masyarakat kecil. Masyarakat kecil merasa sangat terbantu karena dengan pembiayaan mudharabah akan menjauhkan masyarakat dari motif rentenir, selain itu syarat yang dibutuhkan sangat mudah, dan juga pembiayaan mudharabah akan menyelamatkan kaum muslim dari praktik riba yang sangat jelas haram hukumnya.

\section{KESIMPULAN DAN SARAN}

\section{Kesimpulan}

Berdasarkan hasil penelitian dan pembahasan sebagaimana pada bab sebelumnya, maka dapat ditarik kesimpulan bahwa sesuai dengan apa yang telah dijelaskan oleh Kanindo Syariah, mudharabah adalah akad kerjasama antara pemilik dana (shahibul maal) yang menyediakan seluruh kebutuhan modal dengan pihak pengelola usaha (mudharib) untuk melakukan suatu kegiatan usaha bersama. Keuntungan yang diperoleh dibagi menurut perbandingan (nisbah) yang disepakati. Dalam hal terjadi kerugian, akan ditanggung oleh pemilik modal, selama bukan diakibatkan karena kelalaian pengelola usaha. Sedangkan kerugian yang timbul karena kelalaian pengelola akan menjadi tanggung jawab pengelola usaha itu sendiri. Pemilik modal tidak turut campur dalam pengelolaan usaha, tetapi mempunyai hak untuk melakukan pengawasan.

Dalam perhitungan bagi hasil pada pembiayaan mudharabah, porsi yang diberikan adalah 30:70 di mana 30\% adalah bagian nasabah dan 70\% adalah bagian Kanindo. Cara perhitungan juga dijelaskan di awal perjanjian. Pembiayaan bagi hasil mudharabah ini dihitung dari asumsi pendapatan nasabah, yaitu diasumsikan bahwa nasabah akan mendapatkan keuntungan sebesar 10\% dari pembiayaan yang 
diajukan nasabah. Atau bisa juga sesuai dengan kesepakatan kedua belah pihak. Dari asumsi itulah pihak Kanindo bisa menghitung berapa bagi hasil yang akan diberikan oleh nasabah kepada Kanindo.

Peran pembiayaan mudharabah bagi usaha nasabah terlihat dari kegiatan usaha yang dikelola oleh nasabah. Dari yang awalnya kekurangan modal hingga usahanya menghasilkan keuntungan lebih. Selain itu, dari usaha nasabah yang terkendala modal hingga usaha tersebut mampu memenuhi pesanan konsumen. Namun tidak semua usaha yang berjalan mendapatkan keuntungan seperti yang diharapkan. Ada juga usaha yang masih saja belum mengalami perkembangan. Dari beberapa nasabah yang telah memberikan keterangan kepada penulis, penulis juga menemukan adanya nasabah yang tidak menggunakan dana pembiayaan mudharabah untuk usaha atau dengan kata lain, dana yang dipinjam digunakan untuk kebutuhan konsumtif. Hal ini tidak sesuai dengan syarat mudharabah dimana dana yang seharusnya digunakan untuk usaha produktif namun pada kenyataannya tidak. Dan untuk selanjutnya pihak Kanindo mempunyai kebijakan untuk tidak akan lagi memberikan pinjaman dana kepada nasabah tersebut.

Dalam pembiayaan mudharabah, nasabah begitu terbantu dalam menjalankan usaha yang dijalaninya. Hal ini salah satunya dibuktikan dengan semakin banyaknya barang dagangan yang dimiliki nasabah. Selain itu, pembiayaan mudharabah juga memiliki peran bagi perekonomian Indonesia. Diantaranya adalah pembiayaan mudharabah tidak hanya semata-mata bermotifkan ekonomi tetapi juaga motif sosial yaitu diperuntukkan untuk masyarakat kecil. Masyarakat kecil merasa sangat terbantu karena dengan pembiayaan mudharabah akan menjauhkan masyarakat dari motif rentenir, selain itu syarat yang dibutuhkan sangat mudah, dan juga pembiayaan mudharabah akan menyelamatkan kaum muslim dari praktik riba yang sangat jelas haram hukumnya.

\section{Saran}

Berdasarkan hasil analisis dan kesimpulan, maka peneliti memberikan saransaran dalam upaya memajukan Kanindo Syariah, di antaranya; pembiayaan mudharabah memang jawaban sangat pas bila digunakan sebagai pembiayaan usaha nasabah yang tergolong masyarakat kecil. Namun mungkin sebaiknya nasabah yang memiliki usaha lebih diarahkan pada pembiayaan mudharabah. Tentunya untuk nasabah yang sebelumnya pernah menggunakan jasa pembiayaan pada Kanindo Syariah. Karena dengan pembiayaan mudharabah, masyarakat benarbenar merasa terbantu dalam hal penambahan modal.

Dalam upaya melindungi masyarakat dari praktek riba dan rentenir, Lembaga Keuangan Syariah, khususnya Kanindo Syariah memang memberikan andil yang cukup besar. Namun selalu terkendala dengan sumber daya manusia yang ada di Kanindo yang masih sedikit sehingga proses untuk survei pada nasabah harus 
menunggu. Hendaknya ada penambahan karwayan pada bagian Account Officer (AO) sehingga proses survei bisa berjalan cepat mengingat banyaknya calon nasabah yang akan menggunakan produk pembiayaan pada Kanindo Syariah.

Pembiayaan mudharabah ternyata tidak semuanya digunakan untuk usaha. Ada beberapa nasabah yang menggunakan pembiayaan tersebut untuk keperluan rumah tangga (seperti membayar sekolah atau untuk berobat), ada juga untuk keperluan instansi. Maka dalam hal ini, hendaknya pihak Kanindo memberikan pembiayaan mudharabah secara disiplin sesuai dengan prosedur yang telah ada dan mampu memperjelas kegunaan pembiayaan mudharabah pada nasabah sehingga diharapkan tidak ada lagi nasabah yang menggunakan produk pembiayaan mudharabah untuk keperluan selain usaha, lebih dari itu harus dilakukan pengawasan secara teratur agar tidak ada penyimpangan atau mempersempit celah ketidakjujuran dalam pengembalian dana pembiayaan ataupun bagi hasil.

\section{DAFTAR PUSTAKA}

Agustianto. 2008. Baitul Mal Wat Tamwil Dan Pengentasan Kemiskinan. http://agustianto. niriah.com/2008/04/03/baitul-mal-wat-tamwil-bmt-dan-pengentasan-kemiskinan/

Antonio, M.S. 1999. Bank Syariah: Bagi Bankir \& Praktisi Keuangan. Jakarta: Tazkia Institue.

1999. Bank Syariah: Wacana Ulama \& Cendekiawan. Jakarta: Tazkia Institue.

Arikunto, S. 2002. Prosedur Penelitian Suatu Pendekatan Praktek, edisi revisi V. Jakarta: PT Rineka Cipta.

Bardaini, M. 2006. Hubungan Kredit Usaha Baitul Mal Wattamwil (BMT) dengan Pendapatan Usaha Mikro Si Kabupaten Tegal. Skripsi. Semarang: FE-UNNES.

Hafsah, J.M. 2000. ” Kemitraan Usaha” Konsep dan Strategi. Jakarta: Pustaka Sinar Harapan.

Haristiana, H. 2005. Pengaruh Kredit Bagi Hasil BTM Surya Mentari terhadap Peningkatan Pendapatan Pedagang Kecil di Desa Karanganyar Kecamatan Karanganyar Kabupaten Pekalongan. Skripsi. FIS-UNNES.

Hendar, dkk. 2005. Ekonomi Koperasi. Lembaga Penerbit FEUI.

Husen, A. 2005. Strategi Penguatan Usaha Mikro, Kecil, dan Menengah. Yustika, Ahmad Erani (ed). Perekonomian Indonesia: Deskripsi, Preskripsi, Dan Kebijakan. Malang: Bayu Media Publishing.

Indrianto, N., dan Bambang, S. 1999. Metodologi Penelitian Bisnis untuk Akuntansi dan Manajemen, ed. pertama. Yogyakarta: penerbit BPFE.

Irianto, A. 2006. Statistik: Konsep Dasar dan Aplikasinya. Jakarta: Kencana.

Karim, A.A. 2004. Bank Islam Analisis Fiqih dan Keuangan. Jakarta: Raja Grafindo Persada. . 2003. Bank Islam Analisis Fiqih dan Keuangan. Jakarta: IIIT Indonesia.

Lubis, A.E. 2010. Baitul Maal Wat Tamwil (BMT) Suatu Alternatif Sumber Pendanaan Bagi Usaha Mikro/Kecil. http://bmt-link.co.id/category/bmt-adalah/3 Maret 2011.

Mardalis. 1993. Metode Penelitian Suatu Pendekatan Proposal. Jakarta: Bumi Aksara.

O’Sullivan, A. 2003. Economics: Principles in action. Upper Saddle River, New Jersey 07458: Pearson Prentice Hall. 
Qardhawi, Y. 1985. Al-Halal wal-Haram fil-Islam. Darul Ma'rifah ad-Darul Baidha'. AlFalahi, Abu Sa'id dan Aunur Rafiq Shaleh Tahmid. 2000. Halal dan Haram. Jakarta: Robbani Press.

Rivai, V., dan Andria, P.V. 2008. Islamic Financial Management. Jakarta: RajaGrafindo Persada.

Rodoni, A., dan Abdul, H. 2008. Lembaga Keuangan Syariah. Jakarta: Zikrul Hakim.

Sabiq, S. 1987. Fiqhussunah. Marzuki, Kamaluddin A(penterjemah). 1987. Fikih Sunnahl3. Bandung: PT Alma' arif.

Saiman, L. 2009. Kewirausahaan: Teori, Praktek dan Kasus-Kasus. Jakarta: Salemba Empat. Sholihin, A.I. 2010. Buku Pintar Ekonomi Syariah. Jakarta: Gramedia Pustaka Utama.

Sitio, A., dkk. 2001. Koperasi: Teori dan Praktik. Jakarta: Erlangga.

Soemitra, A. 2009. Bank dan Lembaga Keuangan Syariah, Edisi Pertama. Jakarta: Kencana. 